\title{
Meningkatkan Kemampuan Siswa Kelas IX B SMP Negeri 8 Muaro Jambi dalam Menentukan Iklim Matahari pada Pembelajaran Unsur Geografis di Kawasan Asia Tenggara dengan Menggunakan Media Gambar Globe
}

\author{
Akhmad Saiful \\ Guru SMPN 8 Muara Jambi \\ Correspondence email: Akhmadsaiful488@gmail.com
}

\begin{abstract}
There are still many students who do not know how to determine the climate of a country based on its astronomical location. For this reason, the author tries to try to overcome this problem by conducting a Classroom Action research at Muaro Jambi State Middle 8 where the author is on duty. As for the formulation of the problem is whether using globe picture media can improve the ability of class IX B students of Muaro Jambi Middle School 8 in determining the sun's climate in learning geographical elements in the Southeast Asian region? This study aims to improve the ability of class IX B students of Muaro Jambi Middle School 8 in determining the climate of the sun's climate. This research was conducted in three cycles. Each cycle, students are taught how to determine the climate using a globe. The subject matter set for research is the geographical element in the Southeast Asia region. Before doing research, students' ability to determine climate based on their astronomical location obtained $80.77 \%$ of students unable to determine the climate. After doing the research, in the first cycle, which was held in two meetings, $61.54 \%$ of students were able to determine the climate. Then in the second cycle, the results of $76.92 \%$ of students were able to determine the climate and in the third cycle the results were $88.46 \%$ of students able to determine the climate of a country. There was a significant increase in students' abilities. Thus the use of globe image media can be used as an alternative to overcome students' difficulties in determining the climate.
\end{abstract}

Keywords: media use, increasing student ability

\section{PENDAHULUAN}

Cakupan materi IImu Pengetahuan Sosial (IPS) pada jenjang SMP terdiri dari struktur keilmuan geografi, sejarah,ekonomi, dan sosiologi yang dikemas sedemikian rupa sehingga menjadi pokok bahasan atau topik tertentu. IPS mengkaji seperangkat peristiwa, fakta, konsep dan generalisasi yang berkaitan dengan isu sosial. Dalam pelaksanaan proses pembelajarannya dilaksanakan secara terpadu yang mengharuskan guru untuk dapat menguasai seluruh disiplin ilmu yang tersebut.

Berkenaan dengan pembelajaran IPS Geografi, materi tentang iklim telah dipelajari sejak siswa duduk di kelas VII. Untuk menentukan iklim matahari suatu negara dapat dilihat dari letak astromisnya. Seharusnya begitu siswa duduk di kelas IX, mereka telah dapat menentukan iklim matahari suatu negara berdasarkan letak astronomis negara tersebut. Apalagi dalam proses pembelajaran IPS Geografi, banyak dijumpai pokok bahasan yang berkaitan dengan materi tersebut.

Namun kenyataannya masih banyak siswa SMP Negeri 8 Muaro jambi yang belum memahami dalam menentukan iklim matahari suatu negara berdasarkan astronominya. Ini penulis rasakan dalam melaksanakan proses pembelajaran IPS Geografi di kelas IX SMP Negeri 8 Muaro Jambi. Pada materi unsur geografis dikawasan Asia tenggara pembelajaran IPS geografi kelas IX semester genap, penulis mencoba mengajukan pertanyaan kepada siswa tentang iklim Asia Tenggara dengan menampilkan letak astromisnya. Dari 26 jumlah siswa di kelas IX B, ternyata $92,31 \%$ atau 24 siswa tidak bisa menjawab. Hanya 2 orang siswa atau 7,69\% bisa menjawab, inipun terkesan mereka hanya menebak saja karena ditanya alasannya merekapun tidak bisa memberikan argumentasinya.

Berdasarkan analisa penulis, ada beberapa faktor penyebab lemahnya kemampuan siswa dalam menentukan iklim, antara lain :
1. Lemahnya materi prasyarat tentang iklim.

2. Sangat kurangnya media pembelajaran yang dimiliki sekolah.

3. Dalam pelaksanaan proses pembelajaran, guru kurang kreatif dalam membuat media pembelajaran.

4. Kurangnya penguasaan guru terhadap materi yang diajarkan.

Dari uraian di atas, penulis mencoba untuk berusaha memberikan alternatif pemecahan masalah dengan menitikberatkan pada penggunaan media pembelajaran dalam upaya meningkatkan kemampuan siswa dalam mengitepretasikan iklim matahari yang tertuang dalam judul Penelitian Tindakan Kelas (PTK) adalah untul Meningkatkan Kemampuan Siswa Kelas IX B SMP Negeri 8 Muaro Jambi Dalam Menentukan Iklim Matahari Pada Pembelajaran Unsur Geografis di Kawasan Asia Tenggara Dengan Menggunakan Media Gambar Globe. Sehingga diharapakan dapat membantu mereka dalam memahami cara menentukan iklim matahari suatu negara. Disamping itu juga mampu meningkatkan kualitas proses pembelajaran IPS di SMP Negeri 8 Muaro Jambi, Memotivasi guru untuk menggunakan media dalam proses pembelajaran IPS di SMP Negeri 8 Muaro Jambi dan manciptakan budaya penggunaan media pembelajaran dalam proses pembelajaran di SMP Negeri 8 Muaro Jambi.

\section{Kajian Pustaka \\ Hakekat Belajar}

Istilah belajar sudah sangat familier dalam kehidupan kita sehari-hari. Hampir setiap aktifitas kehidupan selalu ada aspek belajarnya. Kegiatan belajar akan terjadi pada setiap manusia dan berlangsung seumur hidup. Beberapa pengertian tentang belajar akan disajikan sebagai berikut :

1. Cronbach memberikan pengertian : "Learning is shown by a change in behavior as result of 
experience" (Belajar adalah perubahan tingkah laku sebagai hasil pengalaman).

2. Harold Spears, mengatakan: "Learning is to observe, to read, to imitate, to try something themselves, to listen, to follow direction" (Belajar adalah dilakukan dengan mengamati, membaca, menirukan, mencoba, mendengarkan, mengikuti petunjuk dan pengarahan).

3. Geoch, mengatakan: "Learning is a change in performance as a result of practice" (Belajar adalah perubahan penampilan sebagai hasil praktik). (Depdiknas, 2004)

Dari beberapa pendapat di atas dapat disimpulkan bahwa hakekat belajar adalah terjadinya perubahan perilaku pada diri seseorang sebagai hasil interaksi dengan lingkungannya. Anak yang tadinya tidak mengerti menjadi mengerti, dari tidak tahu menjadi tahu, anak yang nakal menjadi baik, ini semua merupakan tanda bahwa seseorang telah melakukan proses belajar.

\section{Media Pembelajaran}

Seperti yang telah disimpulkan di atas bahwa belajar pada dasarnya adalah terjadinya perubahan. Perubahan dapat terjadi bila guru dapat menciptakan interaksi yang positif antara guru, anak didik dan terhadap materi pembelajaran. Maka media pembelajaran dapat menjadi solusi untuk membantu terciptanya proses interaksi yang dapat menimbulkan perubahan positif pada anak didik.

Istilah media berasal dari bahasa latin yang merupakan bentuk jamak dari "medium" yang secara harfiah berarti perantara atau pengantar. Makna umumnya adalah segala sesuatu yang dapat menyalurkan informasi dari sumber informasi kepada penerima informasi. Istilah media sangat populer dalam bidang komunikasi. Proses belajar mengajar pada dasarnya juga merupakan proses komunikasi, sehingga media yang digunakan dalam pembelajaran disebut media pembelajaran (Depdiknas, 2003).

Menurut Yudhi Munadi (2008), media pembelajaran dapat dipahami sebagai segala sesuatu yang dapat menyampaikan dan menyalurkan pesan dari sumber secara terencana sehingga tercipta lingkungan belajar yang kondusif di mana penerimanya dapat melakukan proses belajar secara efisien dan efektif.

Jadi jelaslah bahwa media pembelajaran merupakan perantara yang dapat membantu guru dalam penyampaian informasi dalam hal ini adalah materi pembelajaran kepada anak didik sebagai penerima informasi melalui suatu proses komunikasi yang efektif.

\section{Jenis Media Pembelajaran}

Banyak sekali jenis dan bentuk media pembelajaran mulai dari yang sederhana sampai dengan yang canggih. Namun pada dasarnya media dapat dikelompokkan menjadi empat jenis, yaitu media audio, media visual, media audio-visual dan multimedia.

a. Media audio, adalah jenis media yang digunakan dalam proses pembelajaran dengan hanya melibatkan pendengaran peserta didik.

b. Media visual, adalah jenis media yang digunakan hanya mengandalkan indera penglihatan semata,sehingga pengalaman belajar yang diterima peserta didik sangat tergantung pada kemampuan penglihatannya.

c. Media audio-visual, adalah jenis media yang digunakan dalam kegiatan pembelajaran dengan melibatkan pendengaran dan penglihatan sekaligus dalam satu proses

d. Multimedia, adalah media yang melibatkan berbagai indera dalam satu kegiatan pembelajaran. (Rayandra Asyhar, 2010)

Sejalan dengan pendapat Sadiman, dkk (1984) yang mengatakan bahwa jenis media yang lazim dipakai daalam kegiatan belajar mengajar khususnya di Indonesia sebagai berikut:

a. Media Grafis.

Media grafis termasuk media visual, seperti gambar/foto, sketsa, diagram, bagan, grafik, kartun, poster, peta dan globe, papan flanel, papan bulletin.

b. Media Audio.

Media yang berkaitan dengan indera pendengaran, seperti radio, tape recorder, laboratorium bahasa,

c. Media proyeksi diam.

Mempunyai kesamaan dengan media grafik dalam arti menyajikan rangsangan-rangsangan visual, seperti film bingkai, film rangkai, OHP, proyektor tak tembus pandang (Ovaque Projector),film, televisi, video.

Begitu banyaknya media pembelajaran yang dapat dijadikan alternatif penggunaannya dalam proses pembelajaran, maka yang harus diperhatikan adalah pertimbangan pemilihan media yang akan dipakai sehingga media yang dipilih dapat efektif. Ada beberapa hal pertimbangan/kreteria dalam pemilihan media pembelajaran, yaitu karakteristik siswa, strategi pembelajaran, alokasi waktu, biaya, dan waktu yang diperlukan untuk mendapatkannya,

Dalam kaitannya dengan Penelitian Tindakan kelas yang penulis lakukan di SMP Negeri 8 Muaro jambi yang mengangkat masalah rendahnya kemampuan siswa dalam mengintepretasikan iklim matahari suatu negara, maka dalam hal ini penulis mencoba untuk menerapkan media gambar globe sebagai pemecahannya yang secara tinjaun teoritis termasuk dalam media visual.

\section{Media Gambar Globe}

Menurut Sadiman, dkk (1984), pada dasarnya peta dan globe berfungsi untuk menyajikan data-data lokasi. Secara khusus peta dan globe memberikan informasi tentang:

a. Keadaan permukaan bumi, daratan, sungai-sungai, gunung-gunung dan bentuk-bentuk daratan serta perairan lainnya.

b. Tempat-tempat serta arah dan jarak dengan tempat yang lain.

c. Data-data budaya dan kemasyarakatan seperti populasi atau pola bahasa/adat istiadat.

d. Data-data ekonomi, seperti hasil pertanian, industri atau perdagangan internasional.

Kelebihan dari peta dan globe, dipakai sebagai media dalam kegiatan belajar mengajar adalah: 
a. Memungkinkan siswa mengerti posisi dari kesatuan politik, daerah kepulauan dan lain-lain.

b. Merangsang minat siswa terhadap penduduk dan pengaruh-pengaruh geografis.

c. Memunginkan siswa memperoleh gambaran tentang imigrasi dan distribusi penduduk, tumbuh-tumbuhan dan kehidupan hewan serta bentuk bumi yang sebenarnya.

Globe merupakan miniatur bumi. Dengan menggunakan globe, dapat diketahui segala unsur geogafis yang tedapat di bumi. Globe digunakan untuk :

a. Menentukan/merencanakan perjalanan jauh melalui udara atau laut.

b. Propaganda yang berkaitan dengan gempa bumi, arus samudra, dapat diikuti secara baik pada globe.

c. Dengan globe kita dapat melihat hubungan lautanlautan, kontinen-kontinen, daerah-daerah kutub sehingga kita dapat melihat pemandangan yang tidak biasa.

d. Dengan globe pula konsep yang mendasar perbedaan waktu, iklim dan musim.

e. Sangat disarankan penggunaan globe pada langkah awal pelajaran geografi di sekolah.

f. Di setiap sekolah atau bahkan setiap rumah sebaiknya mempunyai globe.

g. Di pendidikan tinggi globe juga sangat penting dalam kaitannya dengan matematika, geografi, climatologi, geodesi, oceanografi, seismologi, geoteknik. (Depdiknas, 2004).

Dari pendapat di atas, inilah yang melatarbelakangi penulis untuk memilih media globe sebagai upaya mengatasi kesulitan anak dalam menentukan iklim. Namun karena keterbatasan globe yang ada, maka penulis mencari solusi dengan meggunakan gambar globe sebagai media.

\section{Iklim}

Iklim adalah keadaan cuaca rata-rata pada daerah yang luas dan dalam waktu yang lama. Untuk menetukan ilkim suatu negara harus diketahui dahulu letak astronomis negara tersebut. Letak astromis merupakan letak suatu negara berdasarkan garis lintang dan garis bujur.

Klasifikasi iklim bermacam-macam. Pada tinjaun teoritis ini, penulis memaparkan :

a. Klasifikasi iklim berdasarkan letak lintang gografis (Iklim Matahari).

Berdasarkan letak lintangnya, iklim di bumi dibedakan menjadi 4 tipe, yaitu:

1. Iklim tropika, terletak antara $231 / 2 \circ$ LU $-231 / 2$ LS

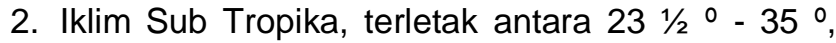
baik belahan bumi utara maupun belahan bumi selatan.

3. Iklim sedang, terletak antara $35 \stackrel{\circ}{-} 66 \stackrel{1}{2} \stackrel{\circ}{\circ}$, baik belahan bumi utara maupun belahan bumi selatan.

4. Iklim dingin atau kutub, terletak antara $661 / 2 \div-90$

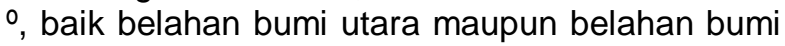
selatan.

b. Klasifikasi Koppen.

Koppen membagi iklim menjadi 5 tipe, yaitu:
1. Iklim A, (iklim hujan tropis), cirinya temperatur

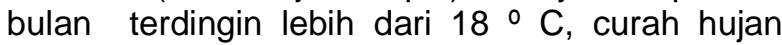
tahunan tinggi.

2. Iklim B, (iklim kering/gurun), cirinya curah hujan lebih kecil dari pada penguapan.

3. Iklim C, (iklim sedang basah), cirinya temperatur bulan terdingin - $3^{\circ} \mathrm{C}$ sampai dengan $-18^{\circ} \mathrm{C}$.

4. Iklim D, (iklim dingin), cirinya temperatur bulan terdingin kurang dari - $3 \stackrel{\circ}{\mathrm{C}}$ dan temparatur bulan terpanas lebih dari $10^{\circ} \mathrm{C}$.

5. Iklim E, (iklim kutub), cirinya pada bulan terpanas suhu kurang dari $10^{\circ} \mathrm{C}$. (Depdiknas ,2004)

Dalam Penelitian Tindakan kelas ini, kemampuan anak yang dilihat dalam menentukan iklim adalah iklim matahari .

\section{Hipotesis Tindakan}

Berdasarkan uraian pada tinjaun pustaka di atas, maka yang menjadi hipotesis tindakan adalah dengan menggunakan media gambar globe dapat meningkatkan kemampuan siswa kelas IX B SMP Negeri 8 Muaro Jambi dalam menentukan iklim matahari pada pembelajaran unsur geogarfis di Asia Tenggara.

\section{METODE PENELITIAN \\ Setting Penelitian}

Penelitian Tindakan kelas ini dilaksanakan di kelas IX B SMP Negeri 8 Muaro Jambi yang berlokasi di Jalan Raya kasang Pudak Rt. 24 Desa Kasang Pudak Kecamatan Kumpeh Ulu Kabupaten Muaro Jambi. Penelitian dilaksanakan pada semester genap, bulan Januari tahun 2012. Jumlah siswa yang menjadi subjek penelitian sebanyak 26 orang yang terdiri dari 11 orang perempuan dan 15 orang laki-laki.

\section{Jenis dan Sumber Data}

Jenis data pada penelitian ini adalah data primer dan sekunder. Data primer adalah kemampuan siswa dalam menentukan iklim dari letak astronomis suatu negara yang diperoleh dari hasil test tertulis dari beberapa buah pertanyaan sedangkan data sekunder adalah tanggapan siswa terhadap penerapan proses pembelajaran dengan penggunaan media gambar globe dalam membantu pemahaman siswa terhadap materi, yang diperoleh melalui kuesioner. Sumber data adalah siswa kelas IX B yang terdiri dari 26 orang siswa.

\section{Alat Pengumpulan Data}

Alat pengumpulan data primer adalah soal yang harus dijawab siswa sedangkan data sekunder dengan menggunakan kuesioner tertutup dalam arti, alternatif jawaban kuesioner telah ditentukan.

\section{Teknik Analisa Data}

Teknik analisa data yang dipakai dalam penelitian ini adalah teknik analisa presentase sederhana. Untuk mengetahui kemampuan siswa dalam menentukan iklim matahari suatu negara dipakai instrument dalam bentuk soal tes tertulis. Dari hasil tes tertulis, maka jawaban benar di beri skor 1 (satu) dan jawaban salah skor 0 (nol) dan nilai yang berikan berbentuk puluhan, sehingga rumus yang digunakan : 


$$
\mathrm{N}=\frac{\text { Jumlah skor perolehan }}{\text { skor ideal/maksimal }} \times 10
$$

Untuk mengetahui tanggapan siswa terhadap penerapan proses pembelajaran dengan penggunaan media gambar globe, digunakan kuesioner tertutup dengan alternatif jawaban dan skor sebagai berikut :

\section{a. Sangat membantu \\ b. Membantu \\ c. Cukup membantu \\ d. Tidak membantu}

Sehingga secara klasikal dapat diketahui presentase jawaban a (sangat membantu, b (membantu), c (cukup membantu) dan d (tidak membantu) atau dengan rumus sebagai berikut :

Jumlah siswa menjawab.....(a,b,c,d) $\times 100=\%$ Jawaban... $(a, b, c, d)$

\section{Jumlah siswa}

\section{Prosedur Penelitian}

Penelitian tindakan kelas ini dilaksanakan dalam tiga siklus yang setiap siklus terdiri dari 4 tahap, yaitu, perencanaan, tindakan, observasi dan refleksi. Siklus I terdiri dari 2 kali tatap muka, alokasi waktu setiap tatap muka adalah 2 × 40 menit. Siklus II dan III masingmasing satu kali tatap muka.

\section{HASIL PEMBAHASAN \\ Kondisi Subjek Penelitian}

Penelitian Tindakan Kelas ini dilaksanakan di kelas IX B SMP Negeri 8 Muaro Jambi desa Kasang Pudak Kecamatan Kumpeh Ulu kabupaten Muaro Jambi. Jumlah siswa 26 orang yang terdiri dari 11 orang perempuan dan 15 orang laki-laki. Latar belakang sosial ekonomi bersifat heterogen .

\section{Siklus I}

Dari hasil analisa tindakan yang dlakukan pada siklus I , pada pertemuan pertama siswa bersemangat mengikuti pembelajaran ini dimungkinkan karena siswa merasa terkesan dengan adanya media pembelajaran yang ditampilkan di depan kelas sehingga motivasi siswa untuk belajar timbul. Namun seperti yang telah dipaparkan di atas, dari hasil pre tes dari satu buah pertanyaan yang diajukan tentang kemampuan siswa dalam menentukan iklim hasil masih sangat rendah yaitu diperoleh hasil, sebanyak 24 orang atau 92,31\% tidak dapat menjawab dan 2 orang atau 7,69 \% bisa menjawab. Kemudian setelah dilakukan tindakan dengan menjelaskan materi pembelajaran dengan media gambar globe selanjutnya didukung dengan kegiatan diskusi sesama mereka, sedikit ada peningkatan. Ini terlihat dari tes yang dilakukan pada akhir tatap muka untuk satu buah pertanyaan tentang kemampuan menentukan iklim diperoleh hasil 8 orang mendapat nilai 10 atau 30,77\% menjawab benar dan 18 orang atau 69,23\% menjawab salah . berarti terjadi peningkatan kemampuan $23,08 \%$ dibanding hasil tes sebelumnya.

Pada pertemuan kedua, sebelum dimulai pembelajaran dilakukan pre tes secara tertulis dengan 1 buah pertanyaan tentang iklim dan 1 buah mengenai hasil pertanian Thailand (lisan) . Khusus pertanyaan tentang iklim, diperoleh hasil 13 siswa memperoleh nilai 10 atau 50\% siswa menjawab benar dan 13 siswa atau $50 \%$ menjawab salah. Suatu peningkatan yang cukup signifikan yaitu $19,23 \%$ dari tes sebelumnya. Hal tersebut dapat disebabkan anak mengulangnya kembali di rumah. Selanjutnya setelah dilakukan proses pembelajaran dan pada akhir pembelajaran dilakukan tes akhir tatap muka tentang menentukan iklim dari letak astronomis dengan satu buah pertanyaan, diperoleh hasil 16 siswa memperoleh nilai 10 atau 61, $54 \%$ siswa menjawab benar dan 38,46\% menjawab salah. Juga terjadi peningkatan kemampuan sebesar 11,54 \%

\section{Siklus II}

Dari hasil analisa pada siklus II ,pertemuan ketiga, sebelum proses pembelajaran atau tindakan diberikan, dilksanakan pre tes tentang menentukan iklim dari letak astronomis dengan jumlah soal 2 buah . diperoleh hasil 19 siswa mendapat nilai 10 atau 73,08 \% siswa menjawab benar. Terjadi peningkatan dari tes sebelumnya sebesar 11, 54\%. Selanjutnya setelah proses pembelajaran atau tindakan dilakukan dilaksanakan tes akhir tatap muka sebanyak 2 buah soal mengenai iklim, diperoleh hasil, 20 orang siswa mendapat nilai 10 atau 76,92 \% siswa menjawab benar. Terjadi peningkatan sebesar $3,84 \%$

\section{Siklus III}

Berdasarkan analisa hasil tindakan pada siklus III, sebelum tindakan diberikan diadakan tes dengan jumlah soal 2 buah, diperoleh hasil 22 orang siswa mendapat nilai 10 atau 84, $62 \%$ siswa menjawab benar dan selebihnya masih belum benar. Terjadi peningkatan sebesar $5,70 \%$

Selanjutnya setelah tindakan diberikan, kemudian di adakan tes pada akhir tatap muka dengan jumlah pertanyaan sebanyak 2 buah, diperoleh hasil 23 siswa mendapat nilai 10 atau 88,46 \% siswa menjawab benar dan sisanya sebanyak 3 orang masih belum benar.

Untuk mengetahui apakah dengan menggunakan media gambar globe dapat membantu siswa dalam meningkatkan kemampuan menentukan iklim berdasarkan letak astronomis. Dari jawaban anak melalui kuesioner , sebanyak 22 siswa atau $84,62 \%$ menjawab sangat membantu,3 orang atau, 11,54\% menjawab membantu dan 1 orang atau $3,85 \%$ menjawab cukup membantu

\section{Pembahasan}

Setelah dilakukan tindakan mulai dari siklus I sampai siklus III, dengan menggunakan media gambar globe diperoleh hasil yang memuaskan. Pada siklus I dilaksanakan dengan dua kali pertemuan diperoleh hasil $61,54 \%$ siswa atau 16 siswa mampu menetukan iklim berdasarkan letak asrtonomisnya dan 10 siswa atau 
$38,46 \%$ belum mampu menentukan iklim dari letak astronomis.

Pada tahap siklus II setelah dilaksanakan tindakan dengan satu kali pertemuan diperoleh hasil 20 siswa mendapat nilai 10 atau $76,92 \%$ siswa mampu menentukan iklim dari letak astromisnya.

Dan pada tahap siklus III dengan satu kali pertemuan setelah silakukan tindakan diperoleh hasil 23 siswa mendapat nilai 10 atau $88,46 \%$ siswa mampu menentukan iklim dan 3 orang atau $11,54 \%$ siswa tidak mampu menetukan iklim berdasarkan letak astronomisnya.

Peningkatan kemampuan ini bisa disebabkan kareana anak merasa terbantu dengan penggunaan media gambar globe dalam membantu meningkatkan kemampuannya dalam menuntukan iklim derdasarkan letak astronomisnya. Terlihat dari jawaban kuesioner yang diterima menunjukan $84,62 \%$ siswa menjawab sangat membantu.

\section{SIMPULAN}

Berdasarkan hasil dan pembahasan dan rumusan masalah yang penulis tetapkan sebelumnya serta hipotesis tindakan, maka dapat disimpulkan bahwa media gambar globe dapat meningkatkan kemampuan siswa kelas IX B SMP Negeri 8 Muaro Jambi dalam menentukan iklim matahari pada pembelajaran unsur geografi di kawasan Asia Tenggara. Ini terlihat dari hasil tindakan sampai siklus III menunjukkan $88,46 \%$ siswa mampu menentukan iklim berdasarkan astronomisnya.

Sejalan dengan kesimpulan di atas bahwa $84,62 \%$ siswa menyatakan penggunaan media gambar globe sangat membantu mereka dalam meningkatkan kemampuan menentukan iklim. Dan 3 orang atau, $11,54 \%$ menjawab membantu dan 1 orang atau $3,85 \%$ menjawab cukup membantu

\section{DAFTAR PUSTAKA}

Depdiknas, Dirjen Dikdasmen, Direktorat Tenaga Kependidikan (2003), Media Pembelajaran.

Depdiknas, Dirjen Dikdasmen, Direktorat Pendidikan Lanjutan Pertama (2004), Materi Pelatihan Terintegrasi, Pengetahuan Sosial, PS-02, PS-04, PS-07.

Rayandra Asyar, (2010), Media Pembelajaran, Raja Grafindo, Jakarta.

Sadiman dkk, (1984), Media Pendidikan, Raja Grafindo, Jakarta.

Yudi Munadi, (2008), Media Pembelajaran Sebuah pendekatan, Gaung Persada Press, Jakarta 